\title{
PERSEPSI MAHASISWA TERHADAP PENGGUNAAN GOOGLE TRANSLATE SEBAGAI MEDIA MENERJEMAHKAN MATERI BERBAHASA INGGRIS
}

\author{
Hidya Maulida \\ Pendidikan Bahasa Inggris, STKIP PGRI Banjarmasin \\ JI S.Adam Komp H. Iyus Blok B No 18 Banjarmasin \\ e-mail: hidya.maulida@gmail.com
}

\section{ABSTRACT}

The use of smartphone for helping students in studying is so familiar. It is used almost in every students' studying activity. For example, it is often used for browsing material needed or for translating english word to indonesian or the opposite. In efforting to comprehend english material, students always try to translate it first. Google translate is a service often used by students to translate.

This study describes of students' perception towards the use of google translate to translate english material. Interview is used in collecting data. The subject is the seventh grade students by considering that based on prelimanary study, they use google translate and they get many assigments to translate English material.

Data shows that students' perception toward the use online dictionary in translating english material is positive. It is stated that google translate giving help a lot. Students can translate faster and complete their assignments. Although there is still weakness of translation result using google translate, google translate saves time in translating english material. The weakness of it overcome by rereading and fixing the translation with context. It is suggested to the students take other benefits of google translate.

\section{Keywords: English material, google translate, perception}

\section{PENDAHULUAN}

Tidak bisa dipungkiri bahwa kemajuan teknologi juga membawa dampak pada dunia pendidikan, baik hal posotif maupun negatif. Salah satu hal posoti misalnya adalah dampakyang medatangkan kemudahan dalam belajar dan aktifitas lainnya yang berhuungan dengan pendidikan. Misalnya kehadiran smartphone, benda ini, dengan segala layanan yang ada didalamnya mendatangkan banyak kemudahan yang membantu dalam belajar.

Sekarang ini, bisa dipastikan bahwa hampir setiap mahasiswa sudah tidak asing lagi menggunakan smartphone untuk membantu mereka dalam belajar atau mengerjakan tugas perkuliahan. Smartphone sering digunakan untuk browsing, mencari berbagai materi yang diperlukan. Selain itu, smartphone juga digunakan untuk menerjemah kata kata bahasa Inggris ke 
bahasa Indonesia dengan menggunakan google translate yang ada pada smartphone.

Mahasiswa pendidikan Bahasa Inggris tentu tidak akan lepas dari materi perkuliahan berbahasa Inggris. Hampir semua mata kuliah memakai buku atau materi berbahasa Inggris. Sebagai upaya untuk memahami materi tersebut maka pada umumnya mahasiswa berusaha menerjemahkan materi tersebut kedalam Bahasa Indonesia.

Google translate atau google terjemahan adalah layanan yang disediakan oleh google Incorporation untuk menerjemahkan teks atau halaman web dalam suatu bahasa ke bahasa lainnya (http//id.m.wikipedia.org/wiki/Google Terjemahan). Walaupun hasil terjemahan menggunakan google translate dapat memberi gambaran umum tentang teks tetapi tidak bisa memberikan terjemahan secara akurat. Misalnya, untuk menerjemahkan frase online course maka hasil terjemahan dari google translate adalah tentunya dengan cara online. Hal ini jauh sekali dengan maksud kalimat secara jika diterjemahkan secara keseluruhan how many times do you join online course and complete it?. Frase online course yang dimaksud pada kalimat tersebut adalah rangkaian pelajaran atau kursus yang dilakukan yang bersifat online, bukan 'tentunya'. Artinya, hasil terjemahan tidak memberikan informasi yang tepat. Namun demikian, berdasarkan survei pendahuluan, banyak mahasiswa yang mengandalkan google translate untuk menerjemah materi berbahasa inggris untuk memahami materi.

Berdasarkan pengalaman peneliti, mahasiswa mengetahui bahwa hasil terjemahan dari google translate untuk sebuah kalimat tidaklah selalu tepat dengan apa yang dikehendaki oleh teks dan konteks aslinya dimana kalimat itu ada. Hal ini mereka ketahui dari hasil pengalaman mereka sendiri ketika materi yang mereka pahami sedang dibahas di kelas. Berdasarkan kondisi tersebut, peneliti mengkaji bagaimana sebenarnya persepsi mahasiswa terhadap penggunaan google translate sebagai media untuk menerjemahkan materi berbahasa Inggris.

\section{KAJIAN TEORI}

\section{Terjemahan}

Menurut Catford (1969:20), terjemahan adalah pergantian materi tekstual dalam suatu 
bahasa (bahasa sumber) dengan padanan materi tekstual dalam bahasa lain (bahasa sasaran) (translation is the replacement of textual material in one language (SL) by equivalent textual material in another language (TL).

Terjemahan menurut Nida and Taber (1969:12) adalah menghasilkan padanan natural yang paling dekat dari pesan bahasa sumber ke dalam bahasa penerima, pertama dari segi makna dan kedua dari segi gaya (Translation consists of reproducing in the receptor language the closest natural equivalence of the source language message, first in terms of meaning and secondly in terms of style)

Menurut Roger T. Bell (1993:5), menerjemahkan pengertian terjemahan menurut Dubois, menyatakan bahwa terjemahan adalah ekspresi dari bahasa sumber dari apa yang diekspresikan dari bahasa sasaran, dengan mempertahankan padanan semantic dan stylistiknya (the definition of translation according to Dubois, states that Translation is the expression in another language (or target language) of what has been expressed in another, source language, preserving semantic and stylistic equivalences)

\section{Google Translate}

a. Definisi

Google Translate adalah layanan mesin terjemahan multibahasa gratis yang dikembangkan oleh Google untuk menerjemah teks, ucapan, gambar, situs, atau real-time video dari satu bahasa ke bahasa lain (Google Translate is a free multilingual machine translation service developed by Google, to translate text, speech, images, sites, or real-time video from one language into another).

b. Manfaat Google Translate

1) Sebagai Penerjemah atau Translator

Ini sebenarnya merupakan fungsi utama, yaitu sebagai translator online, khususnya Google Translate 
Indonesia Inggris, yang memang banyak sekali digunakan dalam kegiatan terjemahan Inggris Indonesia. Namun demikian, dikarenakan pengembangan yang terus dilakukan oleh google terjemahan ini, maka akan banyak sekali manfaat lain Google Translate gratis yang didapatkan selain sebagai penerjemah atau translator.

2) Sebagai Kamus Online Manfaat lain Google Translate yaitu sebagai kamus online (atau terkadang disebut juga "Daring", Dalam Jaringan). Karena, ketika pengguna mesin terjemahan ini melakukan penerjemahan per kata, maka secara otomatis, Google Translate akan menampilkan beberapa pilihan hasil terjemahan kata sumber yang dimaksud di dalam bahasa sasaran.

3) Sebagau Tesaurus Online

Kegunaan Google

Translate selain sebagai penerjemah dan kamus online, juga dapat bermanfaat sebagai tesaurus atau rujukan pilihan makna kata yang sama (sinonim kata) secara daring (online). Selain ragam pilihan sinonim kata, juga ditampilkan tingkat penggunaan kata tersebut.

4) Sebagai Pemeriksaan Ejaan

Google Translate selain sebagai penerjemah bahasa daring yaitu sebagai pemeriksa ejaan kata yang muncul akibat salah ketik (typo). Sangat bermanfaat sekali ketika ingin melakukan pemeriksaan ejaan Bahasa Inggris. 
5) Sebagai Alat Belajar Pengucapan Kata Bahasa

Asing

Bagi yang ingin belajar bahasa asing, misalnya yang ingin Belajar Bahasa Inggris gratis, khususnya bagaimana cara pengucapan kata, google translate dapat digunakan.

Berdasarkan

informasi di atas, maka ada beberapa manfaat dari google translate yang belum diketahui oleh para penggunanya. Sebagian besar pengguna hanya menegetahui fungsi utamanya yaitu untuk menerjemah saja.

c. Kelebihan dan Kekurangan

Sebagai sebuah service, google translate dibuat untuk membantu dalam menerjemah. Google translate mampu menerjemahkan kosa kata dengan cepat. Banyak kata yang sebelumnya tidak ditemukan dalam kamus maknanya dapat ditemukan pada google translate.dia juga memungkinkan penggunanya untuk menerjemah ke berbagai bahasa. Jadi, dengan adanya aplikasi ini, sebenarnya mahasiswa bisa lebih berhemat karena tidak perlu membeli kamus untuk menerjemah ke suatu bahasa. Selain untuk menerjemah sebagai fungsi utamanya, google translate juga memungkinkan penggunanya untuk belajar pengucapan atau pronunciation. Ini merupakan kelebihan yang sangat menguntungkan penggunanya jika dibandingan dengan menggunakan kamus.

Google translate juga mempunyai kelemahan. Sistem yang ada padanya membuat google translate menerjemah kata perkata tanpa mempertimbangkan struktur kata sehingga hasil terjemahan dari suatu kalimat memiliki arti yang jauh berbeda dibanding dengan pengertian aslinya. Dengan kata lain, google translate menerjemah kosa kata jadi sangat memungkinkan terjadi kesalahan jika yang 
diterjemahkan berupa kalimat apalagi teks.

\section{Persepsi}

Menurut kamus lengkap psikologi, persepsi adalah: (1) Proses mengetahui atau mengenali objek dan kejadian objektif dengan bantuan indera, (2)Kesadaran dari proses-proses organis, (3)(Titchener) satu kelompok penginderaan dengan penambahan arti-arti yang berasal dari pengalaman di masa lalu,(4) variabel yang menghalangi atau ikut campur tangan, berasal dari kemampuan organisasi untuk melakukan pembedaan diantara perangsangperangsang,(5)kesadaran intuitif mengenai kebenaran langsung atau keyakinan yang serta merta mengenai sesuatu (Chaplin, 2008).

Persepsi menurut Fieldman (1999) adalah proses konstruktif yang mana kita menerima stimulus yang ada dan berusaha memahami situasi (Perception a contructive process by which we go beyond the stimuli that are presented to us and attempt to construct a meaningful situation). Sedangkan menurut Morgan (1987) persepsi mengacu pada cara kerja, suara, rasa, selera, atau bau. Dengan kata lain, persepsi dapat didefinisikan apa pun yang dialami oleh seseorang (perception refers to the way the work, sound, feel, tastes, or smell. In other works, perception can be defined as whatever is experienced by a person).

Adapun menurut Rakhmat (2009: 51) persepsi adalah pengalaman tentang objek, peristiwa, atau hubunganhubungan yang diperoleh dengan menyimpulkan informasi dan menafsirkan pesan.

Berdasarkan pengertian di atas disimpulkan bahwa persepsi adalah cara berpikir, bekerja serta bersikap pada diri seseorang yang dibentuk oleh pancaindra dan dipengaruhi oleh pengalaman yang dimiliki.

a. Teori Persepsi

Teori transactional yang dicetuskan oleh Mead tahun 1903, Dewey dan Bentley tahun 1949, Ames tahun 1960 (dalam 
Lang,1987:89) menekankan peran pengalaman dalam persepsi dan berfokus pada hubungan yang dinamis antara manusia dan lingkungan. Persepsi dipertimbangkan sebagai suatu transaksi dimana lingkungan, pengamat dan persepsi saling tergantung satu sama lainnya. Teori ini membuat sejumlah asumsi sebagai berikut

1) Persepsi adalah multimodal

2) Persepsi adalah sesuatu yang aktif dan bukan merupakan proses yang pasif.

3) Persepsi tidak dapat dijelaskan dengan pembagian perilaku kedalam perceiver dan dirasakan.

4) Persepsi tidak dapat dijelaskan yang berkaitan dengan respons yang dikondisikan ke stimuli.

5) Hubungan antara orang dengan lingkungan adalah sesuatu yang dinamis.
6) Image lingkungan yang dimiliki oleh pengamat tergantung pada pengalaman masa lalu, motivasi masa sekarang dan sikap.

7) Pengalaman masa lalu diproyeksikan ke situasi masa sekarang dalam hubungannya dengan kebutuhan seseorang.

Mengacu pada teori di atas penjabaran persepsi dijelaskan, mulai dari proses akif hingga hubungan pengalaman dengan situasi masa sekarang. Hal ini terjadi karena orang tersebut dalam mencerna informasi dari lingkungan berhasil melakukan adaptasi sikap, pemikiran, atau perilaku terhadap informasi tersebut berdasarkan pengalaman yang dimilikinya.

b. Persepsi Visual

Secara khusus, Riebel, 1994 menyatakan pentingnya persepsi visual. Persepsi visual sangat berperan karena proses ini menunjukkan kemampuan seseorang untuk mengikuti, menyadari, menyerap arti atau 
makna dari tampilan visual di sekitarnya secara selektif. Ia juga percaya bahwa manusia terbiasa untuk berpikir secara visual atau memiliki gambaran visual dalam otaknya, walau informasi yang diterima berbentuk verbal.

Berdasarkan pendapat di atas dapat disimpulkan bahwa persepsi visual dapat mempengaruhi dalam membayangkan wujud dalam pikirannya yang dipengaruhi oleh pengetahuan dan pengalaman sebelumnya walaupun pesan verbal yang disampaikan.

\section{METODE}

Metode penelitian yang digunakan untuk mengkaji tentang Persepsi Mahasiswa terhadap Penggunaan Google Translate adalah metode kualitatif. Peneliti berusaha menggali apa yang dipikirkan oleh subjek penelitian terhadap penggunaan Google Translate. Dengan pendekatan ini diharapkan bahwa Persepsi Mahasiswa terhadap penggunaan Google Translate di Program Studi Pendidikan Bahasa Inggris STKIP
PGRI Banjarmasin dapat dideskripsikan secara lebih teliti dan mendalam.

Penelitian ini mengambil data dari mahasiwa program studi pendidikan bahasa Inggris karena mereka sebagian besar materi perkuliahan menggunakan bahasa Inggris. Instrument yang digunakan yaitu angket dan wawancara. Angket dan wawancara mengacu pada pedoman yang telah disusun untuk mengetahui persepsi mahasiswa terhadap penggunaan google translate dalam menerjemah materi berbahasa Inggris. Teknik pemilihan sample yang digunakan dalam penelitian ini adalah random karena berdasarkan studi pendahuluan hampir semua mahasiswa program studi bahasa Inggris terbiasa menggunakan google translate dalam aktifitas belajar mereka. Subjek penelitian berjumlah 50 mahasiswa yang dari semester I, III, V, dan VII.

Analisis data dilakukan secara bertahap. Data pertama yang dianalisis adalah data yang diperoleh dari angket yang diberikan dan dilanjutkan dengan data yang diperoleh dari wawancara. Apabila hasil yang ditunjukkan dari data yang diperoleh setelah dianalisis kurang memuaskan, maka peneliti mewawancara lagi subjek peneliti 
sampai diperoleh data yang dianggap kredibel. Aktivitas dalam menganalisis data yaitu data reduction, data display, dan conclusion drawing/verification .

\section{PEMBAHASAN}

Semua mahasiswa mengetahui mengenai google translate sebagai sebuah layanan untuk menerjemah dari satu bahasa ke bahasa lainnya. Namun mereka terlupakan bahwa selain untuk menerjemah, dia juga bisa digunakan untuk belajar pengucapan. Hanya ada satu mahasiswa menyebutkan kegunaan lain dari google translate selain untuk menerjemah yaitu untuk belajar pengucapan dan menambah kosa kata. Mereka terbantu sekali dengan adanya aplikasi ini untuk memahami materi perkuliahan yang berbahasa Inggris yang mana untuk memahaminya mereka harus menerjemah terlebih dahulu. Google translate yang berupa aplikasi tentu saja jauh lebih simpel dibandingkan harus membawa kamus.

Sebagian mahasiswa mengetahui cara menggunakan aplikasi google translate dengan benar, yaitu dengan memasukkan kosa kata yang ingin diterjemahkan kemudian menerjemahkan secara manual dengan pertimbangan mengenai tata bahasa, pemilihan kata dan lain lain. Untuk menerjemah kalimat, mereka juga tetap memasukkkan per kata, tidak satu kalimat. Jadi, jika mereka harus menerjemahkan paragraf maka mereka menerjemahkan dengan mencari arti dari kata yang tidak diketahui kemudian menggabungnya dengan memperhatikan tata bahasa dan lain lainnya.

Namun demikian, sebagian mahasiswa lagi masih belum mengerti sistem kerja aplikasi google translate. Mereka tidak memahami bahwa sistem kerja aplikasi ini adalah menerjemah kata perkata. Oleh karena itu, masih ada mahasiswa yang menerjemahkan kalimat menggunakan google translate dengan memasukkan langsung kalimat yang diterjemahkan kemudian berusaha mencocokkan hasil terjemahan dengan konteks.

Dari hasil angket dan wawancara, terlihat bahwa lebih dari 50\% mahasiswa menganggap dan menggunakan google translate hanya untuk menerjemah, sedikit diantaranya yang menggunakannya untuk belajar pengucapan maupun untuk menambah kosakata atau sinonim. Bisa dikatakan bahwa fungsi lain dari google translate ini terlewatkan oleh mahasiswa. 
Dalam proses perkuliahan, mahasiswa program studi pendidikan bahasa Inggris mempunyai banyak materi perkuliahan berbahasa Inggris. Mahasiswa pada umumnya membuat handout untuk membantu mereka presentasi dalam perkuliahan. Dalam memahami materi berbahasa Inggris tersebut mahasiswa mengaku menggunakan google translate untuk menerjemahkannya ke bahasa Indonesia.

Hampir semua aktifitas kebutuhan menerjemah diambil alih oleh google translate, mulai dari keperluan menerjemah kosa kata saja sampai menerjemah materi teks. Artinya, kamus sudah sangat jarang digunakan oleh mahasiswa. Mahasiswa menggunakan google translate untuk memahami materi mata perkuliahan. Beberapa mahasiswa menyatakan bahwa mereka sering menggunakannya dalam perkuliahan MK Translation, Reading, dan Writing.

Berdasarkan hasil penelitian ini, diketahui bahwa keuntungan yang dirasakan mahasiswa dengan menggunakan aplikasi google translate adalah tentang cepatnya layanan ini untuk menemukan arti dari kata yang mau diterjemahkan. Selain itu,karena ini berupa aplikasi maka tentu saja menjadi lebih simpel dibandingkan membawa kamus. Sedangkan mengenai kekurangan dari aplikasi ini yaitu hasil terjemahan yang terkadang tidak akurat, mahasiswa menyatakan menyiasatinya dengan mencocokkan kembali hasil terjemahan dengan konteks.

\section{KESIMPULAN}

90\% mahasiswa Program Studi Pendidikan Bahasa Inggris STKIP PGRI Banjarmasin menggunakan aplikasi google translate untuk membantu menerjemah materi berbahasa Inggris. Kelebihan dari aplikasi google translate seperti 'cepat' dan 'ringan' ini memuat mahasiswa beralih dari menggunakan kamus cetak. Walaupun ada kekurangan dari aplikasi ini, mahasiswa tetap memiliki persepsi positif terhadap penggunaannya. Mereka meyakini bahwa hasil terjemahan akan tetap akurat selama masih bisa mencocokkan dengan konteks.

\section{SARAN}

Google translate pada dasarnya bisa digunakan tidak hanya untuk menerjemahkan saja. Aplikasi ini juga 
bisa digunakan untuk belajar bunyi atau pengucapan. Bagi mahasiswa program studi pendidikan bahasa Inggris, google translate paling sering digunakan untuk membantu proses menerjemah dari bahasa Inggris ke bahasa Indonesia. Mereka tidak perlu membuka kamus manual yang lebih memakan waktu jika dibandingkan dengan menggunakan google translate. Namun demikian mahasiswa harus memahami sistem kerja google translate; yaitu menerjemah kata perkata, agar mereka bisa mengatasi kelemahannya dan menghasilkan terjemahan yang akurat. Mereka harus mengoreksi hasil terjemahan dengan memperhatikan tata bahasa dan pilihan kata serta berbagai pertimbangan lainnya seperti tata bahasa,idiom dan slang. Jadi, penggunaan google translate harus diikuti dengan penguasaan tata bahasa serta pengetahuan terhadap konteks dari teks yang diterjemahkan.

Dengan mempertimbangkan hasil penelitian ini, yaitu persepsi mahasiswa terhadap penggunaan google translate bersifat positif,maka untuk penelitian yang selanjutkan, disarankan untuk bisa menganalisis secara mendalam mengenai hasi terjemahan dengan menggunakan google translate yang dilakukan oleh mahasiswa. Hal ini untuk memberikan feedback dan pertimbangan mengenai persepsi itu sendiri.

\section{DAFTAR PUSTAKA}

Ardi, Muhammad \& L. Aryani. 2010. Hubungan antara Persepsi terhadap Organisasi dengan Minat Berorganisasi pada Mahasiswa Fakultas Psikologi UIN SUSKA. Jurnal Psikologi, 153-163.

Harisah, Afifah \& Z. Masiming. 2008. Persepsi Manusia terhadap Tanda, Simbol, dan Spasial. Jurnal SMARTeK, 6(1): 29-43.

Sugiyono. 2011. Metode Penelitian Pendidikan (Pendekatan Kualitatif, Kuantitatif, dan $R \& D)$. Bandung: Alfabeta.

Rakhmat, J. 2009. Psikologi Komunikasi. Bandung: Remaja Rosdakarya Offset

https://id.wikipedia.org/wiki/Google Te rjemahan

http://penerjemahsurabaya.com/kelebih an-dan-kekurangan-googletranslate-sebagai-aplikasipenerjemah-bahasa-inggris/

http://gnafashiona.blogspot.co.id/2012/1 0/google-translate.html

https://tarjiem.com/2014/01/manfaatlain-google-translate.html 